\title{
HEALING RATE IN DIABETIC FOOT ULCERS TREATED WITH BIOMEMBRANE AND HYDROCOLLOID POWDER: RANDOMIZED CLINICAL TRIAL
}

\author{
Manuela de Mendonça Figueirêdo Coelho ${ }^{1, *}$ (D), Luciana Catunda Gomes de Menezes² (B), \\ Shérida Karanini Paz de Oliveira ${ }^{\mathbb{B}}$, Ana Débora Alcantara Coêlho Bonfim ${ }^{\mathbb{D} \text {, }}$, Viviane Mamede \\ Vasconcelos Cavalcante ${ }^{1}$ (D) Juliano Teixeira Moraes ${ }^{5}$ (D), Riksberg Leite Cabral² (D)
}

\begin{abstract}
Objective: to evaluate the rate of healing in diabetic foot ulcers treated with a biomembrane of latex proteins from Calotropis procera (BioMem CpLP) when compared to powdered hydrocolloid. Method: randomized controlled clinical trial, registered by the Brazilian Clinical Trial Registry (REBEC), according to protocol RBR-98f3j9, carried out with eight people with diabetic foot, in a diabetic foot clinic, from March to July 2019. In the experimental group $(n=04)$, biomembrane was applied; in the control group $(n=04)$, hydrocolloid powder was used. The healing rate was assessed at 30 and 60 days after starting treatment. Results: no statistical differences were found between the healing rates of the control group and the experimental group in the temporal analysis of the initial 30 days $(p=0.726)$ and in the 60 days following the start of treatment $(p=0.562)$. Conclusion: BioMem CpLP presented healing rates similar to the conventional product, being an effective and low cost alternative for the treatment of diabetic feet.
\end{abstract}

DESCRIPTORS: Diabetic foot. Healing. Nursing. Randomized controlled clinical trial. Stomatherapy.

\section{TAXA DE CICATRIZAÇÃO EM ÚLCERAS DO PÉ DIABÉTICO TRATADAS COM BIOMEMBRANA E HIDROCOLOIDE EM PÓ: ENSAIO CLÍNICO RANDOMIZADO}

\begin{abstract}
RESUMO
Objetivo: avaliar taxa de cicatrização em úlceras do pé diabético tratadas com biomembrana de proteínas do látex de Calotropis procera (BioMem CpLP) quando comparada ao hidrocoloide em pó. Método: ensaio clínico randomizado controlado, registrado pelo Registro Brasileiro de Ensaio Clínico (REBEC), conforme protocolo RBR-98f3j9, realizado junto a oito pessoas com pé diabético, em ambulatório de pé diabético, de março a julho de 2019. No grupo experimental $(n=04)$, realizou-se a aplicação de biomembrana; no grupo controle $(n=04)$, utilizou-se o pó de hidrocoloide. A taxa de cicatrização foi avaliada com 30 e 60 dias após início do tratamento. Resultados: não se constataram diferenças estatísticas entre taxas de cicatrização do grupo controle e do grupo experimental na análise temporal dos 30 dias iniciais $(p=0,726)$ e nos 60 dias subsequentes ao início do tratamento $(p=0,562)$. Conclusão: a BioMem CpLP apresentou taxas de cicatrização semelhantes ao produto convencional, configurando-se como alternativa eficaz e de baixo custo para o tratamento de pés diabéticos.
\end{abstract}

DESCRITORES: Pé diabético. Cicatrização. Enfermagem. Ensaio clínico controlado randomizado. Estomaterapia.

1. Universidade Federal do Ceará - Centro de Ciências da Saúde - Departamento de Enfermagem - Fortaleza (CE), Brazil.

2. Centro Universitário Fametro - Fortaleza (CE), Brazil.

3. Universidade Estadual do Ceará - Centro de Ciências da Saúde - Curso de Graduação em Enfermagem - Fortaleza (CE), Brazil.

4. Centro Universitário Christus - Curso de Graduação em Enfermagem - Fortaleza (CE), Brazil.

5. Universidade Federal de São João del-Rei - São João del-Rei (MG), Brazil.

*Correspondence author: manumfc2003@yahoo.com.br

Section Editor: Maria Angela Boccara de Paula

Received: Dec. 7, 2020 | Accepted: Feb. 20, 2021

How to cite: Coelho MMF; Menezes LCG; Oliveira SKP; Bonfim ADAC; Cavalcante VMV; Moraes JT; Cabral RL. Healing rate in diabetic foot ulcers treated with biomembrane and hydrocolloid powder: randomized clinical trial . ESTIMA, Braz. J. Enterostomal Ther., 2021, 19: e0621. https://doi.org/10.30886/estima.v19.986_IN 


\section{TASA DE CURACIÓN EN LA ÚLCERAS DE PIE DIABÉTICO TRATADOS CON IOMEMBRANA E HIDROCOLOIDE EN POLVO: ENSAYO CLÍNICO ALEATORIZADO}

\section{RESUMEN}

Objetivo: evaluar la taza de curación en pies diabéticos tratados con biomembrana de proteínas de látex de Calotropis procera (BioMem CpLP), en comparación con hidrocoloide en polvo. Método: ensayo clínico controlado aleatorizado, registrado por REBEC, según protocolo RBR-98f3j9, con ocho personas con pie diabético, en clínica de pie diabético, de marzo a julio de 2019. En el grupo experimental ( $n=04)$, se aplicó la biomembrana; en el grupo de control ( $n=04)$, se utilizó polvo de hidrocoloide. La tasa de curación se evaluó a los 30 y 60 días después del tratamiento. Resultados: no hubo diferencias estadísticas entre las tasas de curación en los dos grupos, en el análisis temporal de los primeros 30 días $(p=0,726)$ y en los 60 días posteriores al inicio del tratamiento $(p=0,562)$. Conclusión: la BioMem C $p L P$ presentó tasas de curación similares al producto convencional, siendo alternativa efectiva y de bajo costo para el tratamiento del pie diabético.

DESCRIPTORES: Pie diabético. Curación. Enfermería. Ensayo clínico controlado aleatorizado. Estomaterapia.

\section{INTRODUCTION}

Diabetes mellitus (DM) is a metabolic disease, characterized by the maintenance of high plasma glucose levels. These high levels occur due to the body's incompetence in the production, secretion and/or action of insulin and cause several problems ${ }^{1}$.

Diabetic foot is a complication of DM and is configured as an important health problem at national and international level, and is associated with important complications, such as chronic ulcers, infections, amputations, as well as high mortality rates and the exacerbated cost in the health systems, varying in each geographic region of the planet ${ }^{2}$.

The direct medical costs for treating this condition, in Brazil, in 2014, were US $\$ 361$ million, considering the exchange rate of $1.74 \mathrm{BRL}$, totaling $0.31 \%$ of public health expenses for the time frame. Of this amount, 27.7 million (13\%) were destined for hospitalization and 333.5 million (87\%) for the outpatient segment ${ }^{3}$.

A study published in Brazil in 2020 pointed out that these costs can be underestimated, but even so, there is a high expenditure and urgency of preventive strategies, such as practices to reduce morbidity and mortality from diabetic foot diseases3. Currently, there is a diversity of dressings available on the market. However, the cost of these inputs is still far from the broad access of the low-income population and incompatible with the budget of the Unified Health System (Sistema Único de Saúde- SUS).

When considering the need to reduce costs and the consequent reduction in complications caused by the diabetic foot, there are possibilities of treatment and biological dressings with satisfactory cost-benefit. Regular exercise, potassium permanganate, Acelular Dermal Matrix (ADM) and hyperbaric oxygen therapy proved to be effective adjuvant therapies in the treatment of foot injuries in people with diabetes when associated with conventional therapies ${ }^{1,4}$.

Among therapies for the treatment of diabetic foot injuries, the effects of biological dressings have been widely studied. A 2009 literature review points to the recommendation to use hydrocolloid in the treatment of chronic skin lesions ${ }^{5}$, although it does not report, consubstantially, the use in the treatment of diabetic foot. This coverage is recognized as a relevant technology for the treatment of wounds. However, to use this therapeutic resource, the tissue, type and amount of exudate present in the lesion must be evaluated ${ }^{6}$.

Nevertheless, we are looking for efficient and low-cost inputs that can be produced and distributed on a large scale. Thus, the development of biomembranes originating from plants is mentioned, which studies have been triggered on these, for presenting angiogenic effects and with improvement in healing?

Biomembranes have been developed and used in experimental models of different wounds, showing that the biomembrane of Calotropis procera latex proteins (BioMem $\mathrm{CpLP}$ ) induces tissue neoformation and favors the contraction of wounds ${ }^{7,8}$.

BioMem CpLP actively participates in the inflammatory phase of healing, promoting activation of macrophages, recruitment of neutrophils and release of inflammatory mediators (nitric oxide, tumor necrosis factor - TNF- $\alpha$ - and 
interleukin - IL-1 $\beta$ ). The pro-inflammatory potential of BioMem CpLP appears to directly influence the subsequent phases of the process. The Calotropis procera is a plant called cotton silk, from India and Tropical Africa, which originates BioMem CpLP and has low cost and easy production?.

The biomembrane has positive properties, such as anti-cancer effect, antipyretic and anti-inflammatory potential. Preclinical study, completed in Ceará (2020)9, with the application of the membrane in people with plantar injuries, due to neuropathies from leprosy, it presented satisfactory results regarding the healing of the lesions.

Given the above, the hypothesis of this study was: is BioMem CpLP as effective in the rate of healing of ulcers in feet of diabetic patients as the hydrocolloid powder?

When considering the possibility of effective, low-cost treatment with raw materials available on a large scale in Ceará, Brazil, the study becomes relevant as an efficient and affordable alternative in the treatment of diabetic foot. In addition, the production of studies that demonstrate a higher level of evidence and subsidize evidence-based nursing is considered significant.

Thus, this study aimed to evaluate the rate of healing in diabetic feet treated with BioMem CpLP when compared to powdered hydrocolloid.

\section{METHOD}

Randomized, parallel, clinical trial, conducted from March to July 2019, with people with type 2 diabetes and plantar ulcers, undergoing treatment at a school clinic of a university center located in Fortaleza, Ceará, Brazil, at the Ambulatório do Pé Diabético (APD) .

Participating in the selection were patients who attended a specialized stoma therapy consultation during the period in which the study was carried out, in which a history of habits, anthropometric data and vital signs, in addition to information about the physical examination, were obtained.

The inclusion criteria were: presence of a plantar ulcer with an area smaller than $24 \mathrm{~cm}^{2}$, aged 18 or over and 65 or less and absence of exudate in the lesion.

Patients who had known or identified hypersensitivity to biomembrane-related compounds, dependence on licit or illicit drugs and infection in diabetic foot ulcer diagnosed at the time of recruitment were excluded from the study.

During the study period, 35 people with type 2 diabetes and plantar injuries were undergoing treatment at the referred clinic. 20 people were recruited by invitation during the nursing consultation and, after acceptance, 8 were randomly allocated to the experimental group (EG) and received treatment with BioMem CpLP; and 12 in the control group (CG), in which powdered hydrocolloid was used. We opted for the use of powdered hydrocolloid as compared to biomembrane because this dressing does not have bactericidal or bacteriostatic agents in its formulation, such as BioMem CpLP.

After recruitment, participants were distributed by simple random sampling and taken to the specific treatment group. The process was carried out through the website www.ramdom.org, in which the participants who would receive the intervention and those who would belong to the control group were chosen, using a computerized algorithm.

The discontinuity criteria were: non-return of the participant on the scheduled dates for consultations; appearance of any intercurrent disease, need for medication that could confuse or interfere with the evaluation of the product under investigation; alteration of the lesion during treatment that, in the researcher's opinion, implied the immediate adoption of another therapeutic procedure.

Due to the discontinuity criteria, eight participants made up the final sample of the study, four in each group, which were identified by alpha numeric codes, with the letter E (E01 to E04) for the EG participants and with the letter C (C01 to C04) for individuals in the CG.

There was blinding in the process, that is, the participants did not know the research hypothesis, and it was not identified which would be intervention and control. The visits were performed by stomatherapy nurses or undergoing training in stomatherapy with the help of nursing students, through standardization of care and conduct, as well as records in medical records and telephone contacts when necessary. The researchers were trained in clinical procedures (through the Standard Operating Procedure previously built) and measurement of injuries, in order to ensure uniformity in data collection. 
Before receiving the biomembrane treatment, the participants underwent a patch test, a test to evaluate the hypersensitivity to the membrane, which consisted of applying an adhesive tape with chambers containing the membrane components separately: polyvinyl alcohol (PVA), fraction of the latex of Calotropis procera and, as a negative control, $0.9 \%$ saline. The interpretation of the patch test was based on the readings taken after 48 and 96 hours ${ }^{10}$. No hypersensitivity reactions were observed in the participants in the experimental group.

In the initial consultation, socioeconomic characterization and collection of general health reports, history of hypersensitivity to the components of the biomembrane formulations were carried out, in addition to the history and clinical evaluation of the lesions. The clinical history was investigated, with physical examination (with assessment of the lesion and foot) and some anthropometric data and vital signs (systolic and diastolic blood pressure in the sitting position, pulse, weight and height measurements) were verified, as well as measurement of capillary glycemia.

Also in the first meeting, it was explained in detail how the study would develop, as well as the necessary care at home, such as not wetting the dressing, not discovering the injury, the importance of self-care of the feet, good nutrition and correct use of medicines.

It was discussed the need to attend regularly to consultations that took place 3 times a week, in the outpatient clinic, for 60 days or until the complete healing of the lesions, in which the primary and secondary dressings were changed. Only one of the weekly returns was considered an evaluation visit in both groups, with lesion sizes being measured.

In all consultations, the participants were asked about their well-being, the complaints of the participants and whether they were following the guidelines on home care. Blood pressure, capillary glycemia were checked, and the participant was positioned comfortably and allowed the visualization of the lesion, in which the secondary dressing was removed and, initially, the foot hygiene was performed.

In the treatment of the intervention group, the wound was cleaned with saline and the excess devitalized tissue was removed around it, followed by the application of BioMem $\mathrm{CpLP}$ on the ulcer as a primary dressing. Then, a secondary dressing was performed, consisting of a layer of gauze fixed with bandage and tape.

In the control group, after cleaning the wound with saline and removing excess devitalized tissue around it, powdered hydrocolloid was applied as a primary dressing. Then, the secondary dressing was applied, composed of a layer of gauze fixed with bandage and tape. After the procedure, home guidelines and scheduling of return were reinforced. In addition, nursing records were carried out in both groups. In both groups, it was advised that the dressings shouldn't be changed or manipulated at home, only in the three weekly consultations held at the outpatient clinic.

The clinical data of the nursing consultation were collected using the initial interview form standardized in the APD, and the data regarding the healing rate were recorded in the patient's clinical record, in a specific form, together with the others printed with the clinical data collected in the initial consultations. and subsequent ones. The instrument of the initial interview, applied at the first consultation, together with the new data, was included in the patient's progress chart at each meeting, as well as the measurement of the lesion once a week.

The outcome variable was the Healing Rate (HR), expressed in $\mathrm{cm}^{2} /$ day, which was a measure of the epithelialization speed, being calculated according to Eq. 1:

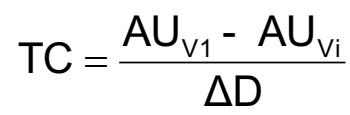

where: $\mathrm{TC}=$ healing rate; $\mathrm{AU}_{\mathrm{V} 1}=$ ulcer area measured in $\mathrm{V} 1 ; \mathrm{U}_{\mathrm{Vi}}=$ ulcer area measured at a follow-up visit $\mathrm{Vi}$; $\Delta \mathrm{D}=$ number of days elapsed between $\mathrm{V} 1$ and $\mathrm{Vi}$.

The parameters for assessing the degree of healing were calculated weekly until the 30-day period, after the end of the follow-up for the study (60 days) or until complete healing occurred. The independent variables were: age, sex, marital status, occupation, literacy, use of insulin, higher glycemic value measured in consultations and associated diseases.

The evaluation of wound healing was performed using values from the measurement of injuries. The lesions were gauged with disposable millimeter rulers, taking the greatest length in height and width so that the areas in $\mathrm{cm}$ were defined ${ }^{2}$. 
In the presence of more than one ulcer, the largest was considered, being referred to as a reference ulcer. However, the unselected ulcer was also assisted by conventional treatment. Complete healing was considered the total epithelialization of the reference ulcer in the absence of a crust. It is noteworthy that the measurements were not taken by the researcher.

The continuous quantitative variables were initially analyzed by the Shapiro-Wilk test to verify the normality of the distribution. For descriptive statistics, the mean and standard deviation were calculated.

For associations between the dependent and independent variables, Student's $t$ test, Fisher's Exact Test, were used, with an agreed confidence level of $95 \%$ and a p-value $<0.05$. The data were processed using the Statistical Package for the Social Sciences (SPSS) software, version 22.0, and presented in tables.

The study was approved according to applicable legislation, according to Resolution 466/12 of the National Health Council, by the Research Ethics Committee (CEP), by issuing the Consubstantiated Opinion under number 3,164,340, issued on February 22, 2019 by the CEP of the Faculdade Metropolitana da Grande Fortaleza, and Certificate of Presentation for Ethical Appreciation 08284019.4.0000.5618. Participants signed the Free and Informed Consent Form. The clinical trial is registered on the Plataforma de Registro Brasileiro de Ensaios Clínicos (ReBEC), according to code RBR-98f3j9.

\section{RESULTS}

Of the 35 participants, 20 met the inclusion criteria and agreed to participate in the study, with 8 allocated to the EG and 12 to the CG. During the research, the EG had 4 losses due to discontinuity criteria, ending with 4 patients. In the $\mathrm{CG}$, there were 8 losses due to discontinuity criteria, ending also with 4 participants (Fig. 1).
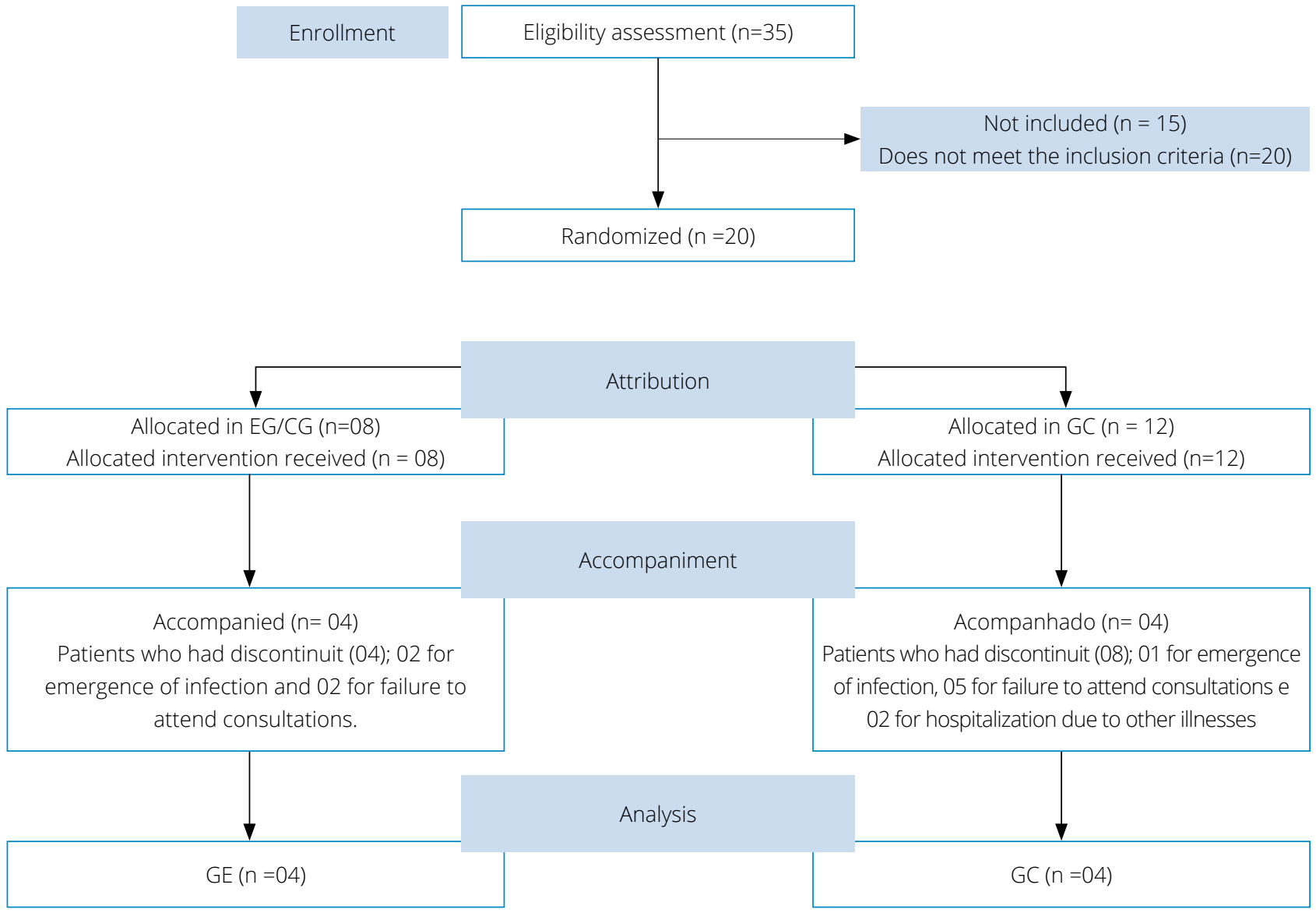

$\mathrm{GE}=$ experimental group; GC= control group.

Figure 1. Representation of the sample's constitution. Fortaleza (CE), Brasil - 2020. 
Three (37.5\%) of the lesions were located in the hallux (one of which was amputated), 2 (25\%) in the plantar fascia and $3(37.5 \%)$ in the calcaneus. All of them presented liquefaction necrosis, but without infectious signs. When proceeding to the data analysis, it was observed that the mean age of the CG was $52.50(\sigma=5.5)$ years, and $51.75(\sigma=5.1)$ years in the $\mathrm{EG}$, with $\mathrm{p}$-value $=0.197$ (Student's $\mathrm{t}$ test). Table 1 shows the association of independent variables between groups.

Table 1. Independent variations of the control group and the experimental group. Fortaleza (CE), Brasil - 2020.

\begin{tabular}{lccc}
\hline Variable & $\begin{array}{c}\text { Control Group } \\
\text { N (\%) }\end{array}$ & $\begin{array}{c}\text { Experimental Group } \\
\text { N (\%) }\end{array}$ & $\mathbf{p}^{*}$ \\
\hline Work & $01(25.0)$ & 0.486 \\
\hline Yes & $03(75.0)$ & $03(75.0)$ & \\
\hline No & & & 1.0 \\
\hline Marital Status & $02(50.0)$ & $02(50.0)$ & $\mathbf{1 . 0}$ \\
\hline With partner & $02(50.0)$ & $02(50.0)$ & \\
\hline No partner & & $01(25.0)$ & \\
\hline Gender & $01(25.0)$ & $03(75.0)$ & \\
\hline Female & $03(75.0)$ & & \\
\hline Male &
\end{tabular}

* Fisher's exact test

According to the data, the homogeneity of the participants in the sample of the CG and EG was confirmed with regard to age $(p=0.197)$, occupation $(p=0.486)$, marital status $(p=1.0)$ and sex $(p=1.0)$.

Consider that some of the independent variables in this study could influence treatment, as they are directly related to human physiology, as well as to the participants' understanding and performance for self-care. Some of these variables are shown in Table 2.

Table 2. Independent variables of the control group and the experimental group. Fortaleza (CE), Brasil - 2020.

\begin{tabular}{lccc}
\hline Variables & $\begin{array}{c}\text { Control Group } \\
\mathbf{N}(\%)\end{array}$ & $\begin{array}{c}\text { Experimental Group } \\
\mathbf{N}(\%)\end{array}$ & $\mathbf{p}^{*}$ \\
\hline Literacy & & & $\mathbf{1 . 0}$ \\
\hline Yes & $03(75.0)$ & $03(75.0)$ & \\
\hline No & $01(25.0)$ & $01(25.0)$ & $\mathbf{1 . 0}$ \\
\hline Use of insuline & & & 1.0 \\
\hline Yes & $03(75.0)$ & $01(75.0)$ & \\
\hline No & $01(25.0)$ & & \\
\hline Associated diseases & & $03(75.0)$ & \\
\hline Yes & $03(75.0)$ & $01(25.0)$ & \\
\hline No & $01(25.0)$ & & \\
\hline
\end{tabular}

${ }^{*}$ Fisher's exact test

Thus, as observed in relation to the variables "literacy", "use of insulin" and "associated diseases", the groups also did not show a statistically significant difference ( $\mathrm{p}=1.0$ in all variables). The highest glycemic value identified for each participant was also observed during the data collection period, in which the GC glycemic average was $208 \mathrm{mg} / \mathrm{dl}(\sigma=64.5)$ and in the 
experimental group of $234(\sigma=51.0)$, with p-value $=0.547$ (Student's T test), confirming the homogeneity of the group in relation to the postprandial glycemic values.

All participants used oral hypoglycemic agents, $75 \%$ of whom associated the hypoglycemic agent with insulin therapy. Of the 6 who had associated diseases, 4 (66.66\%) reported being hypertensive, 1 had kidney disease and the other, heart disease.

Intergroup healing rates were calculated 30 and 60 days after the start of treatment (Table 3).

Table 3. Healing rates in $\mathrm{cm}^{2}$ of the first 30 days (TX01) and of the subsequent 60 days (TX02), between groups. Fortaleza (CE), Brasil - 2020.

\begin{tabular}{cccccccccc}
\hline & E01 & E02 & E03 & E04 & C01 & C02 & C03 & C04 & p $^{*}$ \\
\hline TX01 & 0.016 & 0.007 & 0.422 & 0.166 & 0.266 & 0.050 & 0.093 & 0.040 & $\mathbf{0 . 7 2 6}$ \\
\hline TX02 & 0.014 & 0.004 & 0.018 & 0.085 & 0.033 & 0.016 & 0.106 & 0.033 & 0.562 \\
\hline
\end{tabular}

*T test

The analysis showed no statistically significant differences between the groups in the temporal analysis of the initial days $(\mathrm{p}=0.726)$, in the 30 days following the start of treatment $(\mathrm{p}=0.562)$ and in the 60 days observed $(\mathrm{p}=0.846)$.

There was a considerable decrease in the size of the lesions, but no evidence to suggest that the treatment with hydrocolloid powder is superior to that performed with the biomembrane. It is noteworthy that participant C02 achieved complete healing at 60 days.

Intragroup healing rates were calculated 30 and 60 days after the start of treatment (Table 4).

Table 4. Difference in healing rates in $\mathrm{cm}^{2}$ of the first 30 days (TX01) and of the subsequent 60 days (TX02), within the same group. Fortaleza (CE), Brasil - 2020.

\begin{tabular}{lcc}
\hline & $\begin{array}{c}\text { TX01 } \\
\mathbf{p}^{*}\end{array}$ & $\begin{array}{c}\text { TX02 } \\
\mathbf{p}^{*}\end{array}$ \\
\hline Control Group & 0.290 & 0.605 \\
\hline Experimental Group & 0.261 & 0.301 \\
\hline *T test & &
\end{tabular}

\section{DISCUSSION}

The results showed that there were no statistical differences between the healing rates between the CG and the EG in the temporal analysis of the initial 30 days $(p=0.726)$ and in the 60 days following the start of treatment $(p=0.562)$.

Experimental studies in laboratories, carried out in Minas Gerais and Ceará, corroborate the findings of this trial, in which the use of latex biomembranes, although not showing superior results when compared to other products consecrated for this purpose, has relevance regarding wound healing cutaneous in animals ${ }^{7,8}$.

As noted, no statistically significant difference was identified between treatment periods within the same group, confirming that the biomembrane showed good interaction at all stages of the wound healing process.

This corroborates the study developed in São Paulo, which experimented with the latex biomembrane in the healing of skin ulcers, showing that this proved to be a satisfactory therapeutic option for the treatment of injuries, reinforcing that this therapeutic alternative is shown, effective, easy to handle and with no risk of transmitting infectious diseases ${ }^{10}$.

In the study on screen, similarity was observed between the groups surveyed. The similarity of the groups in case-control research is relevant, as it ensures the same characteristics among the participants, converging so that the intervention is the divergent variable that predominates in the study. In case-control studies, it is not uncommon to find bias in the sampling procedure, a problem that can be minimized with samples belonging to the same groups, even if not representative, with pairing, population-based studies and the use of several control groups ${ }^{11}$. 
The data presented in the literature are not yet unanimous in relation to associations between gender and the presence of diabetic foot. However, studies produced in Goiânia, Alagoas, Pernambuco and Sergipe have evidenced the predominance of women with DM and the prevalence/risk of diabetic foot ${ }^{12-15}$.

The level of education of individuals enhances the preventive practice of complications. There is an inference between low education, low purchasing power and increased risk of foot ulceration, most likely due to the difficulty of acquiring adequate food, as well as access to health services and limitation in buying suitable shoes to prevent injuries ${ }^{16}$.

The low level of education is predictive for the development of complications in people living with DM, as it is considered that people with insufficient years of education do not perform adequate care with their feet, such as wiping between the toes, as well as maintaining hygiene and proper nail cutting. A study carried out in Londrina pointed out that the lower level of education directly influences the ability of individuals to better understand the condition to which they are submitted and preventive care ${ }^{16}$.

The patients who participated in the present study used oral hypoglycemic agents and $75 \%$ of them associated the hypoglycemic agent with insulin therapy. The use of insulin in patients with type $2 \mathrm{DM}$ is not usually the first choice for treatment. The delay in introducing this therapy exposes patients to several consequences, due to the prolonged time of poor metabolic control. It is known that the delay is sometimes due to some barriers and fears, especially with regard to the risk of hypoglycemia ${ }^{17}$.

Thus, important scientific entities, such as the American Diabetes Association (ADA), European Association for the Study of Diabetes (EASD), as well as those of the American Association of Clinical Endocrinologists (AACE) and the Sociedade Brasileira de Diabetes (SBD) support the use of insulin and do not seem to associate the use of it, necessarily, with a potential for severity, but with more effective control of blood glucose levels and, consequently, with less complications ${ }^{17}$.

Of the 6 participants who presented associated diseases, 4 (66.66\%) reported being hypertensive, 1 had kidney disease and the other, heart disease. The National Health Survey (Pesquisa Nacional de Saúde-PNS) found a pattern of risk factor for chronic diseases, mainly Systemic Arterial Hypertension (SAH) associated with diabetes ${ }^{18}$. Another study that evaluated the responses of adults in the PNS 2013 points out SAH (65\%) as a factor related to the development of ulcers in the lower limbs in people with $\mathrm{DM}^{19}$.

It is known about the difficulties of wound healing in diabetic patients. Retrospective cohort study, developed in Belo Horizonte, with people with lower limb ulcers, in the period from 2011 to 2013, found that 23\% of individuals with DM healed their wounds, in the period of 600 days, while among non-diabetics, healing rate was around $63 \%$, with an important statistical difference in relation to the survival of the 2 groups $^{20}$.

Thus, the preliminary results presented in this manuscript pointed to the possibility of the effective use of the membrane, in order to subsidize stomatherapy nurses in the use of this product. In addition, it is suggested that the trial be followed up, as well as health education actions focusing on self-care, so that ulcers in remission do not present a recurrence.

The limited number of participants is considered a limitation of the study, justifying the continuity of the clinical trial in order to search for more clinical evidence on the use of the membrane in foot injuries of people with DM.

\section{CONCLUSION}

There were no statistically significant differences in the healing rate between the CG and EG in the temporal analysis of the initial days ( $p=0.726)$, in the 30 days following the start of treatment $(p=0.562)$ and in the 60 days observed ( $p=0.846)$, confirming the null hypothesis indicated in the study, that BioMem CpLP presents healing rates similar to an existing coverage on the market, thus configuring itself as an effective and low cost alternative for the treatment of diabetic foot ulcers. 


\section{AUTHORS 'CONTRIBUTION}

Conceptualization: Coelho MMF; Methodology: Coelho MMF e Menezes LCG; Writing - First version: Coelho MMF e Cavalcante VMV; Writing - Review \& Editing: Coelho MMF, Menezes LCG, Oliveira SKP, Bonfim ADAC, Cavalcante VMV, Moraes JT e Cabral RL; Supervision: Coelho MMF

\section{DATA STATEMENT AVAILABILITY}

All data were generated or analyzed in the present study.

\section{ACKNOWLEDGMENTS}

We thank the Centro Universitário Fametro for their support in carrying out this study.

\section{REFERENCES}

1. Oliveira JZ, Ferreira LO, Magnus GA, Micheletto LB, Campos LC, Grazziotion TC. Úlcera no pé diabético: manejo clínico adjuvante. Acta med 2018;39(1)101-7. [cited on 07 dec 2020]. Available at: https://ebooks.pucrs.br/edipucrs/acessolivre/periodicos/actamedica/assets/edicoes/2018-1/arquivos/pdf/10.pdf

2. Jeffcoat WJ, Vileikyte L, Boyko E, Armstrong DG, Boulton AJM. Current Challenges and Opportunities in the Prevention and Management of Diabetic Foot Ulcers. Diabetes care 2018;41(4):645-52. https://doi.org/10.2337/dc17-1836

3. Toscano CM, Sugita TH, Rosa MQM, Pedrosa HC, Rosa RS, Bahia LR. Annual Direct Medical Costs of Diabetic Foot Disease in Brazil: A Cost of Illness Study. Int J Environ Res Public Health 2018;15(1):89. https://doi.org/10.3390/ijerph15010089

4. Andrade SM, Santos ICRV. Oxigenoterapia hiperbárica para tratamento de feridas. Rev Gaúcha Enferm 2016;37(2):1-8. https:// doi.org/10.1590/1983-1447.2016.02.59257

5. Pinheiro LS, Borges EL, Donoso MTV. Uso de hidrocolóide e alginato de cálcio no tratamento de lesões cutâneas. Rev Bras Enferm 2013;66(55):760-70. https://doi.org/10.1590/S0034-71672013000500018

6. Ministério da Saúde (BR). Manual do pé diabético: estratégias para o cuidado da pessoa com doença crônica. Brasília (DF): Ministério da Saúde; 2016.

7. Rosa JPP. Efeitos da biomembrana de látex de seringueira na cicatrização de feridas experimentais em coelhos. Rev Univ Vale Rio Verde (Online) 2016;14(2):821-40. [cited on 06 dec 2018]. Available at: http://periodicos.unincor.br/index.php/ revistaunincor/article/view/3344/2592

8. Ramos MV, Alencar NMN, Oliveira RSB, Freitas LBN, Aragão KS, Andrade TAM et al. Wound healing modulation by a látex protein-containinga polyvinyl alcohol biomembrane. Naunyn Scmiedebergs Arch Pharmacol 2016;389:747-56. https://doi. org/10.1007/s00210-016-1238-2

9. Ramos MV, Freitas APF, Leitão RFC, Costa DVS, Cerqueira GS, Martins DS, et al. Anti-inflammatory latex proteins of the medicinal plant Calotropis procera: a promising alternative for oral mucositis treatment. Inflamm Res 2020;69(9):951-66. https://10.1007/s00011-020-01365-7

10. Frade MAC. Biomembrana de látex para tratamento de úlceras cutâneas. ESTIMA Braz J Enterostomal Ther 2004;2(4). [cited on 7 dec 2020]. Available at: https://www.revistaestima.com.br/estima/article/view/161

11. Hulley SB. Delineando a pesquisa clínica: uma abordagem epidemiológica. $3^{\text {a }}$ ed. Porto Alegre: Artmed; 2008.

12. Oliveira JC, Taquary SAS, Barbosa AM, Veronezi RJB. Pé diabético: perfil sociodemográfico e clínico de pacientes hospitalizados. R bras ci Saúde 2018;22(2):15-20. https://doi.org/10.22478/ufpb.2317-6032.2018v22n1.23034

13. Tavares TA, Costa LJSF, Sales MLH, Moraes MM. Fatores de risco para ulceração e amputação de extremidades inferiores em portadores de diabetes mellitus. Rev Bras Promoç Saúde 2016;29(2):278-87. [cited on 07 dec 2020). Available at: https:// periodicos.unifor.br/RBPS/article/view/4268/0

14. Dourado MA, Santos ICRV. Adesão aos cuidados de prevenção do pé diabético. ESTIMA Braz J Enterostomal Ther 2015;13(4). [cited on 02 dec 2019). Available at: https://www.revistaestima.com.br/index.php/estima/article/view/111 
15. Figueiredo EOC, Barros FO, Santos EF, Pimentel TS, Góis CFL, Otero LM. Avaliação do grau de risco para pé diabético em indivíduos com diabetes mellitus tipo 2. Rev enferm UFPE on line 2017;11(Supl. 11):4692-9. [acesso em 11 jan 2020 ]. Available at https://periodicos.ufpe.br/revistas/revistaenfermagem/article/view/231211/25218

16. Silva JMTS, Haddad MCFL, Rossaneis MA, Vannuchi MTO, Marcon SS. Fatores associados à ulceração nos pés de pessoas com diabetes mellitus residentes em área rural. Rev Gaúcha Enferm 2017;38,(3):e68767. https://doi.org/10.1590/19831447.2017.03.68767

17. Sociedade Brasileira de Diabetes. Diretrizes da Sociedade Brasileira de Diabetes 2019-2020. São Paulo: Editora Clannad; 2019.

18. Malta DC, Bernal RTI, Iser BPM, Szwarcwald CL, Duncan BB, Schmidt MI. Fatores associados ao diabetes autorreferido segundo a pesquisa nacional de saúde, 2013. Rev Saude Publica 2017;51(supl.1):12s. https://doi.org/10.1590/s1518-8787.2017051000011

19. Targino IG, Souza JSO, Santos NMG, Davim RMB, Silva RAR. Fatores relacionados ao desenvolvimento de úlceras em pacientes com Diabetes Mellitus. J res: fundam care online 2016; 8(4):4929-34. https://doi.org/10.9789/2175-5361.2016.v8i4.4929-4934

20. Oliveira MF, Viana BJF, Matozinhos FP, Silva MMS, Pinto DM, Moreira AD, et al. Feridas em membros inferiores em diabéticos e não diabéticos: estudo de sobrevida. Rev Gaúcha Enferm 2019;40:e20180016. https://doi.org/10.1590/1983-1447.2019.20180016 